Spring 2016

\title{
Environmental Philosophy as A Way of Life
}

Toby Svoboda

Fairfield University, tsvoboda@fairfield.edu

Follow this and additional works at: https://digitalcommons.fairfield.edu/philosophy-facultypubs Copyright 2016 Indiana University Press. A post print has been archived with permission from the copyright holder.

\section{Peer Reviewed}

\section{Repository Citation}

Svoboda, Toby, "Environmental Philosophy as A Way of Life" (2016). Philosophy Faculty Publications. 31. https://digitalcommons.fairfield.edu/philosophy-facultypubs/31

\section{Published Citation}

Svoboda, Toby. "Environmental Philosophy as A Way of Life." Ethics \& the Environment 21.1 (Spring 2016): 39-60.

This item has been accepted for inclusion in DigitalCommons@Fairfield by an authorized administrator of DigitalCommons@Fairfield. It is brought to you by DigitalCommons@Fairfield with permission from the rightsholder(s) and is protected by copyright and/or related rights. You are free to use this item in any way that is permitted by the copyright and related rights legislation that applies to your use. For other uses, you need to obtain permission from the rights-holder(s) directly, unless additional rights are indicated by a Creative Commons license in the record and/or on the work itself. For more information, please contact digitalcommons@fairfield.edu. 
This is a post-print version of Toby Svoboda, "Environmental Philosophy as a Way of Life," Ethics \& the Environment 21:1 (2016).

\section{Environmental Philosophy as a Way of Life}

\section{Introduction}

Environmental philosophy is particularly well-suited to facilitate a revival of a philosophical art of living, or the practice of philosophy as a way of life. The notion that philosophy involves the practice of living well is most often associated with Hellenistic figures (e.g., Epicurus, Epictetus, and Seneca), but it is also present in some modern philosophical writers (e.g., Thoreau). However, despite interest in this tradition of philosophy from the likes of Michel Foucault, Martha Nussbaum, and Pierre Hadot, the practice of philosophy as a way of life is virtually absent at the present time.

In this paper, I argue both that philosophy as a way of life is a tradition worth reviving and that environmental philosophy is a promising branch of philosophy to enact this revival. First, I sketch what constitutes philosophy as a way of life, which includes both some conception of the good life and an array of spiritual exercises that assists one in living according to that conception. I then discuss a connection between possessing virtue and leading the good life, a connection of great importance to ancient and modern practitioners of philosophy as a way of life. Next, I offer an argument for why this tradition of philosophy is worth reviving at the present time. The remainder of the paper is devoted to exploring the prospects for a distinctively environmental approach to philosophy as a way of life.

Given its emphasis on environmental virtue and its rich resources for developing spiritual exercises, I argue that environmental philosophy as a way of life is both a robust and attractive option compared to what we might call "purely theoretical” approaches to 
environmental philosophy. My argument is that, because environmental philosophy involves normative claims for human beings, we need some way of internalizing the relevant norms and acting in accordance with them. This is precisely what environmental spiritual exercises provide. Purely theoretical approaches tend to fall short in this respect, for they specify norms without providing means to internalize, enact, or care about them. This is an aspect of what Lisa Kretz calls the “theory-action gap.” Using the example of climate change, she notes that the ethical case for decisive action is overwhelming, and yet many of us fail to act accordingly (Kretz, 2012). Others have made similar claims about what I am calling purely theoretical approaches, including that these overlook the psychology of motivation (Booth, 2009) and pay insufficient attention to philosophy of action (Coeckelbergh, 2015; Goralnik and Nelson, 2011). The general problem for purely theoretical approaches is that they do not address the theory-action gap. Such approaches might provide unassailable arguments regarding how we ought to act and yet have very little impact on how human beings end up acting, even in the case of those who understand and accept the relevant arguments. I shall argue that environmental philosophy as a way of life offers an attractive way to bridge this gap, and for two reasons: first, it provides techniques (i.e., spiritual exercises) for internalizing relevant norms, such as those advocated by some theory; second, it takes seriously the idea that certain attitudes and actions regarding the environment contribute to one's own flourishing, thus providing some motivation to take on those attitudes and actions.

\section{Philosophy as a Way of Life}

In order to live well as a human being, it seems helpful to have both (1) some conception of the good life and (2) some array of practices or "spiritual exercises” (Hadot, 1995) whereby one is able (or becomes able) to lead such a life. Historically, philosophers have provided resources to assist in both (1) and (2), presenting competing views of the good 
life and developing practices whereby one actually could lead or at least approximate some specified good life. Yet while contemporary philosophers have continued to think about what constitutes the good life, very few carry on the ancient tradition of thinking about spiritual exercises, and fewer still advocate practicing them (although cf. Irvine, 2008). Following Hadot, by "spiritual exercises" I shall mean endeavors “intended to effect a modification and a transformation in the subject who practiced them” (Hadot, 2002: 6). We might also call such practices “ascetic exercises,” understood in the Greek sense of askesis as transformation, for the point of performing them is to bring about a transformation in oneself, one to be conducted in accordance with some conception of the good life. Spiritual exercises may include practices such as meditation, physical exercise, diet regimens, manual labor, journalwriting, self-examination, and so on. What makes these spiritual exercises is that their goal is to bring about an internal change in oneself, rather than an external or material change about oneself. As Arnold Davidson says, these exercises “were spiritual because they involved the entire spirit, one’s whole way of being” (Davidson, 1995). The term “spiritual” does not require that these exercises be religious in nature (although they can be) but only that they be concerned with an inner transformation of the subject practicing them. This is why the term “ascetic" or "transformative” exercises would serve just as well, but I use the more common “spiritual exercises,” as employed by Hadot and others.

Philosophers are not the only ones who have pursued (1) and (2), of course. Most obviously, various religious and monastic traditions contain both rich conceptions of the good life and sophisticated spiritual exercises. Given that these endeavors are not exclusive to philosophy, something further must be said regarding what distinguishes philosophy as a way of life from non-philosophical (or not purely philosophical) approaches to (1) and (2). As will become clear from cases discussed below, a distinctively philosophical approach to (1) and (2) involves rational reflection on both what the good life is and how one might cultivate 
oneself to lead the good life. I will not attempt to define what exactly counts as rational reflection. There are competing conceptions of rationality available, and this controversial issue cannot be resolved with adequacy here. However, we can expect that a rationally reflective approach to (1) and (2) will include argumentation, appeals to coherence, reasoned objections to competing views, and other devices familiar to philosophers-it presumably will not include dogmatic appeals to divine revelation, historical authorities, or prevailing social norms . Thus, we may say that philosophy as a way of life involves both accepting (1) some conception of the good life and engaging in (2) spiritual exercises to help one lead the specified good life, where (3) these tasks are undertaken in a rationally reflective fashion. In other words, to pursue philosophy as a way of life is to accept some conception of the good life on the basis of rational reflection and to engage in spiritual exercises that, again on the basis of rational reflection, one takes to be conducive to the accepted conception of the good life. Plausibly, this combination provides tools for bridging the theory-action gap, for (2) provides techniques for living in accordance with (1). Most ethical theories defend some conception of the good life but have nothing to say about how it might be achieved in practical terms.

Rational reflection regarding (1) is familiar, since contemporary value theorists continue to provide arguments for and against certain theories of the good life, such as hedonistic, preference-satisfaction, and objective list theories. The Hellenistic schools of philosophy largely shared the view that the good or flourishing life consisted of ataraxiaroughly, freedom from disturbance or stress-although they differed on what constituted ataraxia and how it was to be achieved (Nussbaum, 1994: 41). For example, the Epicureans held that the good life consisted of freedom from pain, a state most reliably acquired by focusing on only natural and necessary pleasures (Long and Sedley, 1987: 113-114). Alternatively, the Stoics advocated living according to reason, which they took to require 
subduing one’s passions and freeing oneself from their disturbances (Nussbaum, 1994: 316358).

We can evaluate different conceptions of the good life in terms of whether and how well they deliver on the goal of ataraxia, such as by assessing the competing arguments offered by the Epicureans and Stoics for their respective views. But we also can evaluate how conceptions of the good life as ataraxia compare to other conceptions, such as by considering objections to Epicurean and Stoic positions. A life devoted to the pursuit of ataraxia might be incompatible with pursuits that prima facie have great value, such as cultivating personal relationships. Since there is always a risk of substantial disturbance in such relationships (e.g., due to a friend's betrayal), it might be difficult to see how pursuing ataraxia would be compatible with maintaining personal relationships. Yet it would be deeply counter-intuitive to hold that personal relationships have no place in the flourishing life. So we might conclude that the Stoics and Epicureans put too much emphasis on freedom from disturbance as the end of the good life (Nussbaum, 1994: 9).

Initially, it might be less clear what would count as rational reflection regarding spiritual exercises. A useful example of this is provided by Stoic and Epicurean disagreement regarding the praemeditatio malorum, or the practice of meditating on future ills, such as death. Both schools agreed that a person leading the good life would not be troubled by the prospect of her own death, but they diverged on whether meditation on death was a valuable exercise. According to Cicero, Epicurus suggested that one should not engage in the praemeditatio malorum in general, since doing so is apt to cause unnecessary disturbance (i.e., pain), thus inhibiting one's enjoyment of the good life. Rather than distressing oneself by considering future ills—some of which, death excluded, are not inevitable anyway—one should meditate on pleasure, including the past pleasures that one has enjoyed (Cicero, 1927: 3.15.32-33; Foucault, 2005: 468-469). Unlike meditating on painful prospects, meditating on 
pleasurable experiences in one's past can itself bring a new pleasure in this very act of recalling the past. For the Epicurean, this spiritual exercise is therefore to be preferred to that of the praemeditatio malorum, because the former is far more effective at achieving the freedom from pain that constitutes one's flourishing.

The Stoics, conversely, suggested that meditating on death is a useful exercise because it can mitigate or remove anxiety from which we might otherwise suffer. For example, Marcus Aurelius holds that we should engage in meditative practices that see death as simply a part of the natural order:

... at all times awaiting death with contented mind as being only the release of the elements of which every creature is composed. If it is nothing fearful for the elements themselves that one should continually change into another, why should anyone look with suspicion upon the change and dissolution of all things? For this is in accord with nature, and nothing evil is in accord with nature (Aurelius, 1983: 2.17).

Here the praemeditatio malorum is thought to remove certain misconceptions and instill a proper understanding of death, namely that it is part of a rationally ordered nature and therefore not an ill after all. If we do not meditate on death, there is a risk both that we shall retain the mistaken view that death is an evil and that we shall suffer distress from this mistaken view.

Both Epicurus and Marcus Aurelius offer competing arguments for their divergent views on the value of the praemeditatio malorum. To assess these arguments is an instance of rational reflection on (2). We may ask which argument is stronger, whether either is subject to damaging objections, whether the arguments rely on implausible premises, and so on. In 
this case, we can examine whether the praemeditatio malorum is successful in mitigating anxiety about one's own death, considering Stoic and Epicurean arguments for and against the practice. Of course, in making their arguments, both Marcus Aurelius and Epicurus appeal to doctrines of the Stoic and Epicurean school, respectively. Thus, the task of rationally evaluating (2) is not here entirely separate from either the task of rationally evaluating (1) or the task of rationally evaluating other philosophical doctrines that may be relevant. For example, Marcus Aurelius relies on the Stoic idea that nature is rationally ordered, a view that is rejected by the atomistic Epicureans. Thus, in evaluating the Stoic advancement of the praemeditatio malorum, we may need to investigate whether something like the Stoic doctrine is true and, if not, what difference this would make for the value of meditating on future ills as a spiritual exercise. But this does not alter the fact that we can evaluate the effectiveness of the spiritual exercises themselves, even if that evaluation does not occur in isolation.

Finally, we should distinguish the study of philosophy as a way of life from the practice of philosophy as a way of life. As an example of the former, a scholar might be interested in studying (1)-(3) in the case of the Stoics but have no interest in incorporating (1)-(3) in her own life. Conversely, the Stoics themselves put (1)-(3) into practice in their own lives. While I assume that the study of philosophy as a way of life is a valuable enterprise, in the end I am interested in the practice of philosophy as a way of life. As will become clear, my position is that environmental philosophy offers an attractive set of possibilities for this practice.

We are now in a position to sketch what counts as environmental philosophy as a way of life. If philosophy as a way of life consists of (1) accepting a conception of the good life and (2) adopting spiritual exercises that help one lead the good life, where (3) both these activities are pursued in a rationally reflective manner, then environmental philosophy as a 
way of life consists of (1') accepting an environmental conception of the good life and (2') adopting a set of environmental spiritual exercises meant to cultivate that good life, where (3) both these ends are pursued in a rationally reflective manner. ${ }^{1}$ This formulation is appropriately open-ended, given the many forms of (1') and (2') that seem possible. I discuss the prospects for (1') and (2') in the second half of this paper.

\section{Virtue and Flourishing}

It is no accident that practitioners of philosophy as a way of life tend to emphasize the virtues. First, virtue plays an important role in various conceptions of the good life. Second, many spiritual exercises are designed to cultivate virtue and extirpate vice. Viewed as an excellent character trait, virtue is sometimes taken to be at least partly constitutive of an individual's own flourishing (Hursthouse, 1999). ${ }^{2}$ Some ancient philosophers held that virtue was even sufficient to secure a flourishing life. Plotinus, for example, holds that the genuine sage (i.e., the fully virtuous person) could maintain his connection to the Good even while being tortured to death, and Epicurus held that the sage would find such torture pleasant (Cicero, 1927: 2.7.17-18; Plotinus, 1969: 1.4.13). Alternatively, Aristotle held that virtue was necessary but not sufficient to secure a flourishing life. Since factors outside of one's control (e.g., poor health) can negatively impact one's flourishing, even being fully virtuous is not a guarantee that one will lead the good life. Accordingly, Aristotle holds that those who insist that one can flourish while being tortured to death are mistaken (Aristotle, 1999: 1153b). Nonetheless, even on this less radical Aristotelian view, being a virtuous individual is required in order to flourish or achieve the good life, inasmuch as virtue is at least part of

\footnotetext{
${ }^{1}$ I do not suggest a (3'), because I see no reason to suspect that the rational reflection involved would or should be any different in kind from that involved in non-environmental forms of philosophy as a way of life.

${ }^{2}$ I will not attempt the difficult task of determining precisely what a virtue is. While this is an interesting question, the more general conception of virtue as a good character trait is sufficient to allow discussion of what role virtue plays in the good life.
} 
what constitutes such flourishing. ${ }^{3}$ In fact, Aristotle also argues that certain virtues, such as greatness of soul, enable one to bear misfortune well (Aristotle, 1999: 1124a). While this does not cancel his claim that external factors play some role in whether or not one is flourishing, it does suggest that being virtuous can reduce the impact such factors can have on our flourishing, although not to the extent supposed by Epicurus and Plotinus.

An interest in virtue is natural for any philosophy concerned with how to lead the good life. At least in part, this is because leading a good life is not plausibly construed as a series of discrete actions, as if living well consisted of merely performing a sequence of disconnected acts. It is doubtful whether such a series would count as a life at all, much less a life that is properly led. Rather, leading a life seems to require integration among one's various actions, an integration rooted in one’s character. For if one’s actions were not rooted in some character, it is difficult to see how those actions would have the unity or coherence that seems necessary to constitute a genuine life. To put matters simplistically for the moment, one's character is constituted by certain traits, some of which may be good (virtues) and some of which may be bad (vices). Leading a good life might be taken to require in part that one have a good character, or one constituted by virtues. At any rate, since this was the view of many Hellenistic philosophers, it is not surprising that many of them emphasized the importance of virtue, since being virtuous is arguably necessary for the good life they hoped to pursue.

Further, in attempting to lead the good life, looking to virtuous exemplars seems helpful (Hursthouse, 1996). This is especially so given that developing virtuous character traits may be tied up with internalizing principles of action, forming certain habits, or modifying one’s dispositions and desires. Here an abstract rule or decision procedure regarding how to act is likely insufficient, and so it may be useful to consider actual virtuous

\footnotetext{
${ }^{3}$ Importantly, virtue need not be limited to morally excellent character traits alone. We can recognize a wide range of excellent character traits, including intellectual and physical virtues, for example. It may be that the good life includes both moral and non-moral virtues.
} 
individuals, learning from the qualities they display, how they themselves became virtuous (e.g., through some spiritual exercises they might perform), the activities they avoid, the motivations they report having, and the advice they might offer. Indeed, if they are able to communicate with us, such exemplars also can serve as teachers of the good life. Especially when it comes to pursuing (2), it is no doubt extremely difficult to train oneself without aid. More experienced practitioners can offer guidance and support, corrections to various mistakes (e.g., faulty techniques), and so on. One sees this in the letters of Seneca to Lucilius, in which the teacher offers his pupil advice, encouragement, and correction as Lucilius attempts to lead the Stoic life (Seneca, 1961; Foucault, 1986: 53).

Finally, I should note that placing an emphasis on virtue as a constituent of the good life does not require one to adopt a virtue ethic as a matter of normative ethical theory, although it is compatible with doing so. That is, one need not be a virtue ethicist in order to recognize the importance of virtue for the good life. One reason for this is that to pursue (1)(3) is not to commit oneself to a normative ethical theory that might serve as a competitor to other such theories. To see why this is so, note that pursuing (1) and (2) is compatible with accepting either a consequentialist or a deontological normative ethic. While proponents of both these kinds of theory do allow an important role for virtue (Nussbaum, 1999), neither consequentialists nor deontologists are virtue ethicists in the proper sense. Yet it is perfectly conceivable for someone both to pursue philosophy as a way of life by cultivating certain virtues and to follow the dictates of some version of consequentialism (e.g., by maximizing happiness) or deontology (e.g., by always respecting persons as ends-in-themselves). On nonvirtue ethical theories, there is at least nothing wrong about generally pursuing (1) and (2) in addition to satisfying one's moral obligations. ${ }^{4}$ Further, some non-virtue ethicists coherently maintain that we have a moral obligation to develop virtues. Kant, for example, holds that

\footnotetext{
${ }^{4}$ Of course, there might be specific cases in which pursuing (1) and (2) at a particular time would conflict with some other moral obligation one has, such as when one has a duty to interrupt some spiritual exercise in order to assist someone in an emergency situation. But cases like this do not threaten the general point.
} 
one has a moral duty to herself to cultivate virtuous dispositions (Kant, 1999: 6:446; Svoboda, 2012). Yet Kant is not a virtue ethicist, since this duty fits within a broader deontological framework.

Why Philosophy as a Way of Life Is Worth Reviving

I take it as a truism that any human person has good reason to lead a good life and that many of us in fact desire to do so. We can assume broad agreement on this general point. Controversy arises when some specific conception of the good life is put forward. Not surprisingly, there is disagreement on a host of issues that seem relevant here, such as the role of pleasure in the good life and the contribution of virtue to one's own flourishing. Because of this disagreement, becoming clear on available accounts of the good life, thinking about their respective merits and deficiencies, and adopting some such conception-effectively pursuing (1) — is worthwhile. But if the pursuits of thinking about the good life and accepting some conception of it are worthwhile, then surely it is also worthwhile to consider and implement means by which we might succeed in living according to that conception. This would involve the development and practice of certain exercises meant to cultivate oneself in such a way that leading the specified good life becomes possible or more manageable. Effectively, this is to pursue (2). Lacking this, we would have failed to bridge the theoryaction gap. That is, we might have a sophisticated, plausible, and well-argued theory of the good life, but this by itself would provide us no help in actually living well. We need means to become the sorts of persons specified by the theory in question, to put that theory into practice. Spiritual exercises played precisely this role in the philosophical traditions I have mentioned.

The foregoing considerations are not sufficient to establish that philosophy as a way of life is worth reviving, for various non-philosophical approaches are available in pursuing 
both (1) and (2). One might be impressed by some organized religion's conception of the good life and commence the ritual or meditative practices associated with it, or one might read self-help books and act on their advice. If we are to believe that a distinctively philosophical approach to (1) and (2) is worth reviving, then we need some plausible reason to think that a rationally reflective approach to (1) and (2) is worth pursuing. Importantly, providing a compelling reason to accept this need not entail that non-philosophical approaches to (1) and (2) are inferior to a philosophical one. Perhaps philosophy as a way of life is preferable to these other approaches, but I will not argue for that claim here. Instead, I suggest that philosophy as a way of life is worth reviving at least as an additional option to these other approaches. There are two quite plausible reasons to accept this weaker claim.

First, a philosophical approach to (1) and (2) should be attractive to those who already put significant value on rational reflection. Given that the practice of philosophy as a way of life involves subjecting both conceptions of the good life and suggested spiritual exercises to close rational scrutiny, those who are skeptical of available accounts of the good life may find this philosophical approach attractive. Philosophy as a way of life encourages its practitioners to evaluate and question competing approaches to (1) and (2). There are a variety of reasons why, on reflection, one might rationally reject some candidate for the good life-perhaps it is internally incoherent, incompatible with our best science, morally indefensible, dependent upon fantastical historical claims or dubious appeals to divine revelation, and so on. For those who value such reflection, the practice of philosophy as a way of life would seem to offer a valuable approach to thinking about the good life and ways to lead it.

Second, a philosophical approach to (1) and (2) offers ways to navigate the controversy and disagreement that are inevitable when it comes to questions regarding competing conceptions of the good life and associated spiritual exercises. While it would be naïve to think that philosophical argumentation will produce a single consensus on what the 
good life is and what spiritual exercises will help us lead it, rational reflection nonetheless allows for reasoned dialogue among defenders of competing views. If we are uncertain what the good life is, we can consider the relative merits of competing accounts, as well as objections that have been raised against them. One might thereby come to a justified (or at least reasonable) position regarding (1) and (2), be able to defend that position with plausible arguments, and be able to critique competing positions. Lacking such argumentative tools, we might be unable to say why some way of life is preferable to others, and this might leave us at a loss regarding which way of life to adopt and/or which spiritual exercises to undertake. Given its commitment to rational reflection, the practice of philosophy as a way of life is attractive in part because it offers a non-dogmatic way to navigate widespread disagreement regarding how to live well.

\section{Environmental Virtue and Conceptions of the Good Life}

In the remainder of this paper, I argue both that environmental philosophy has the resources to renew the practice of philosophy as a way of life and that this is a worthwhile goal. In the present and subsequent sections, I respectively suggest that there is substantial material in environmental philosophy for developing plausible versions of (1') environmental conceptions of the good life and (2') environmental spiritual exercises meant to realize or at

least approximate such conceptions. Although I develop neither a full-fledged conception of the environmental good life nor a worked out set of environmental spiritual exercises, this discussion will indicate some plausible and attractive forms environmental philosophy as a way of life might take.

Environmental philosophers recently have placed a great deal of emphasis on environmental virtues and vices (Cafaro and Sandler, 2005; Sandler, 2009). Among environmental virtues, we might count benevolence toward non-human animals, humility 
regarding one's place in the natural world, respect for nature, and temperance in one's use of natural resources. Among environmental vices, we might count malevolence toward animals, an arrogant attitude of human superiority, and greedy exploitation of natural resources. While many of those who write on environmental virtue and vice accept some kind of environmental virtue ethic as a normative theory, an emphasis on environmental virtue in one’s thinking does not require one to adopt such a theory (Svoboda, 2015). For example, Paul Taylor makes much of the virtue of respect for nature, yet he develops a broadly deontological framework for moral obligation to biotic entities (Taylor, 1986: 198-218). Without defending the content of his account, this example suggests that recognizing the importance of environmental virtues does not require accepting an environmental virtue ethic perse.

It is an open question whether or not environmental virtues belong to a distinct class of virtue. On the “extensionist” view, environmental virtues (and vices, mutatis mutandis) are simply non-environmental virtues extended to cover environmental cases. On the "nonextensionist” view, at least some environmental virtues belong to a distinct class—-they are essentially environmental in character and thus do not consist merely of extending nonenvironmental virtues (Sandler, 2005: 219-220). I will not take a position here on this controversial issue. Fortunately, it is not necessary for me to take a position on this matter, because both positions share the view that there are genuine environmental virtues and vices. If nothing else, we at least should accept the extensionist claim that commonly recognized virtues and vices sometimes cover environmental cases. Surely it is possible to be benevolent toward non-human animals or greedy in one’s use of natural resources, for example, even if the benevolence or greed at issue is no different in kind from that involved in nonenvironmental cases. Since I take it that either extensionism or non-extensionism is true, and 
since on either view there are genuine environmental virtues, I conclude that there are genuine environmental virtues.

For this reason, it is plausible to suppose that one can be environmentally virtuous. Now if we accept the view that virtue is necessary (if not sufficient) for flourishing, then we have some initial reason to suspect that possessing environmental virtues could contribute to a flourishing life. ${ }^{5}$ Upon reflection, it seems reasonable to identify an environmentally virtuous person as flourishing to a greater degree than an environmentally vicious person, all else being equal. So-called "last person” scenarios—in which the last person on Earth destroys entire ecosystems for amusement, but without any possibility of his actions affecting present or future humans_-make this explicit. The last person's actions seem not only to be morally wrong (Sylvan, 2003) but also to indicate the presence of bad character traits (perhaps arrogance or malevolence) that seem inimical to the last person’s own flourishing (O'Neill, 1992). We might ask what sort of person would engage in such horrific actions (Hill, 2005). The last person contrasts with an environmentally virtuous person, say one who displays the traits of benevolence toward non-humans and respect for nature. We might think that, all else being equal, the environmentally virtuous person is flourishing to a greater extent than the last person. This judgment is well-explained by the notion that virtue is constitutive of flourishing, or that the virtues benefit their possessor (Hursthouse, 1999). This is not primarily a point about the moral badness of the last person's character and the moral goodness of the virtuous person's character. Rather, the point is that the last person seems to fail in the task of leading a good life, and this is harmful to himself. Alternatively, the environmentally virtuous person seems to avoid such harm to herself, arguably because she is benefited by her own virtues.

\footnotetext{
${ }^{5}$ It is possible that some but not all virtues contribute to flourishing, and it is also possible that environmental virtues are among those that do not so contribute, but I see no reason to suppose that environmental virtues would be exceptional in this way.
} 
In addition to a rich literature on environmental virtue, there is also no shortage of environmentally virtuous exemplars to whom we might look, such as Rachel Carson, Aldo Leopold, John Muir-and Henry David Thoreau is an obvious case (Cafaro, 2005). We may plausibly take Thoreau to have pursued philosophy as a way of life (Hadot, 2005). He famously announces in Walden, "I went to the woods because I wished to live deliberately, to front only the essential facts of life, and see if I could not learn what it had to teach, and not, when I came to die, discover that I had not lived” (Thoreau, 2004: 88). Much of that book is an illustration of Thoreau's commitment to environmental virtues like simplicity and respect for nature. Moreover, Thoreau seems to have valued such virtues for the contribution they can make to a flourishing life. In his "Life Without Principle,” he excoriates his fellow citizens for being more concerned with "business" and material acquisition than with living well, suggesting that wisdom essentially involves both knowing how to lead the good life and choosing to pursue it (Thoreau, 2013). Indeed, Thoreau arguably practiced environmental philosophy as a way of life, conceiving of the good life as constituted in part by environmental virtues, as well as engaging in various spiritual exercises (see below) meant to instill and reinforce them.

To those who share something close to Thoreau's conception of the good life, he seems to offer a compelling exemplar. For those who do not accept Thoreau's conception of the good life, there are other environmentally virtuous exemplars to whom they might appeal. The existence of such exemplars provides further reasons to think that environmental philosophy as a way of life can get off the ground. First, it suggests that cultivating environmental virtue is feasible, given that others have already done so. Second, the pool of such exemplars provides a kind of resource to those who wish to lead an environmentally virtuous life. We can look to the lives of Carson, Leopold, Muir, and Thoreau in order to compare different conceptions of the environmentally virtuous life, and we can draw upon 
their experiences and counsel in order to avoid pitfalls and pursue avenues that are more likely to be successful in leading such a life.

In general, both a rich literature on environmental virtue and a history of environmentally virtuous individuals suggest that environmental philosophy has the resources to pursue (1'), developing a conception of the good life that (at least in part) includes the possession of environmental virtues. Developing a conception of (1') seems worthwhile, given the plausibility of the view that the environmentally virtuous person flourishes to a greater extent than the environmentally vicious person, all else being equal. Of course, divergent conceptions of (1') are possible. Evaluating different candidates for the environmental good life would require becoming clear on their relative merits and deficiencies through rational reflection. Environmental philosopher are already pursuing this task to some extent, particularly in the literature on environmental virtue.

\section{Environmental Spiritual Exercises}

Members of the Hellenistic schools practiced a variety of exercises meant to assist their pursuit of (1). Some of these exercises, such as keeping journals, functioned to internalize relevant beliefs and values. The best known example of this is the Meditations of Marcus Aurelius, in which he urges himself to remember and live by the doctrines of the Stoic school and reflects on how to overcome disturbances in his soul. We might view this exercise of journal-writing as helping to secure one’s commitment to a certain conception of the good life, as well as sculpting the habits and desires conducive to that good life. The practice allows one to remind oneself of the values to which she is committed, to exhort herself to act in accordance with them, to reflect on how and why her recent behavior has failed (or succeeded) in approximating these values, and so on (Foucault, 1997). This qualifies as a spiritual exercise, given that it aims to bring about a transformation in the 
practitioner, cultivating her habits and desires in accordance with some conception of the good life.

Another ancient spiritual exercise consisted of self-examination, in which one reflected on how she had lived during the previous day. Here one considers whether her actions and thoughts were in accordance with the relevant conception of the good life, identifying mistakes that might not have been obvious otherwise (Seneca, 1979: 3.36). As Foucault notes, the point of this exercise was not to feel remorse but rather "to enhance the rational equipment that ensures a wise behavior” (Foucault, 1986: 62). Suppose that one’s conception of the good life involves the absence of the emotions of hatred, shame, and envy. Self-examination at the end of one's day would then include considering whether one harbored those emotions at any point since waking that morning. If one finds that she has experienced these emotions, further self-examination may diagnose their causes.

Understanding these causes may provide the "rational equipment" that can help one avoid such emotions in the future, such as by making one realize that these emotions depend on our own interpretation of events or of the actions of other persons, interpretations over which we have some control. This spiritual exercise thus can render one more sensitive to obstacles to the good life, and it can equip one to overcome these obstacles.

For an environmental spiritual exercise, reconsider the case of Thoreau, who was committed to various practices conducive to a conception of the good life that places a high value on simplicity, acceptance of nature (Hadot, 2005), and perhaps even ataraxia. These practices included walking excursions, voluntary poverty, and journal-writing-but Thoreau's approach to manual labor is especially instructive. He held that the beans he planted at Walden would be partially consumed by wildlife and thus "grow for woodchucks partly." Rather than worrying about this, Thoreau suggests that the "true husbandman will cease from anxiety, as the squirrels manifest no concern whether the woods will bear 
chestnuts this year or not...” (Thoreau, 2004: 161). Thoreau's position is similar to a central thought of Epictetus: "Do not seek to have everything that happens happen as you wish, but wish for everything to happen as it actually does happen, and your life will be serene” (Epictetus, 1928: 8). Attempting to make the world fit one’s desires is likely to meet with disappointment, whereas fitting one's desires to the world can decrease anxiety. Thoreau seems to agree that some matters are not worth disquiet—it is sometimes best to acquiesce, such as by accepting nature's consumption of a portion of the product of one's labor. This attitude of “true husbandry” helped make Thoreau’s manual labor into a spiritual exercise, a point previously urged by the Stoic Musonius Rufus, who held that manual labor can serve to teach and internalize philosophical lessons (Rufus, 2011).

Thoreau’s manual labor counts as an environmental spiritual exercise because it helped to instill acceptance of nature, which he deemed to be a component of the good life. This is a spiritual exercise because it is a practice meant to effect a transformation in the practitioner. It is an environmental spiritual exercise because it employs interaction with the natural world in order to craft or strengthen an attitude regarding nature. If successful in crafting or strengthening a component of the good life, such a practice helps one bridge the theory-action gap. It provides a practical way to achieve a component (e.g., acceptance of nature) of the good life. For this reason, environmental spiritual exercises offer resources for putting values and norms into practice. Unlike purely theoretical approaches, environmental philosophy as a way of life does not merely specify what constitutes the good life-it also provides the "rational equipment” (to borrow Foucault’s phrase) for achieving such a life.

Spiritual exercises need not be thoroughly practical. They also can involve a theoretical component. Hadot argues that virtually all of the Greco-Roman schools of philosophy advocated "the view from above," a kind of vantage point on the world and on 
human affairs meant to contribute to one’s progression toward ataraxia. For Epicureans, Stoics, Platonists, and even the Skeptics,

philosophy was held to be an exercise consisting in learning to regard both society and the individuals who comprise it from the point of view of universality. This was accomplished partly with the help of a philosophical theory of nature, but above all through moral and existential exercises. The goal of such exercises was to help people free themselves from the desires and passions which troubled and harassed them (Hadot, 1995: 242).

As Hadot notes, adopting the view from above has both theoretical and practical dimensions. On the one hand, a "philosophical theory of nature" — such as the Stoic idea that nature is infused with a providential, cosmic reason (Hadot, 1995)—-may help one abstract from individual concerns, stress, pain, and so on. If one views the universe as a providentiallygoverned cosmos, for example, it is perhaps easier to find meaning in one's suffering, seeing it as part of the whole and achieving some degree of equanimity with regard to it. On the other hand, adopting the view from above (e.g., through meditation) might itself serve as a spiritual exercise, offering means by which to overcome disturbances, perhaps by making it easier to view them from a third-person perspective. In effect, this can help one regard her own situation from "the point of view of universality," rather than from a first-person perspective in which such disturbances are experienced immediately. Importantly, the view from above is not equivalent to "the view from nowhere," the latter of which may be impossible to adopt for human beings. The view from above is still a view from somewhere, but from a place that affords some distance in observing the phenomenon in question. For example, one might view one's own suffering as if it were the suffering of someone else. This 
still involves a perspective, namely a third-person one, but it allows for some degree of detachment from the suffering one might otherwise experience. Unlike the view from nowhere, the view from above seems possible to adopt, such as through an act of imagination.

Like the ancient schools, environmental philosophy includes various theories that seem consonant with the view from above. Many environmental philosophers urge us to recognize the intrinsic value of non-human nature and consequent moral standing of nonhuman entities (Rolston, 1982), and many have emphasized future generations and our obligations to them, requiring us to consider how present actions may impact even the distant future (Shrader-Frechette, 2000). Arguably, these theoretical positions encourage something close to the view from above, because adopting them expands our vantage point beyond merely individual, present, or human concerns. These environmental philosophical views may have a practical dimension relevant for one’s own flourishing. Like the Stoics' cosmic reason, seeing ourselves as only part of an intrinsically valuable nature, or as but one of many equally important generations, may make it easier to put our own disturbances, stress, and suffering in perspective, viewing it as part of some larger sequence, collection, or whole. Prima facie, these views seem to offer theoretical resources for dealing with threats to our own ataraxia, helping us to abstract from a first-person perspective on our own disturbances and instead adopting "the point of view of universality" with respect to them. This also may help us cultivate environmental virtues, such as acceptance of nature or benevolence toward intrinsically valuable non-humans. If all this is correct, then such theories in environmental philosophy can be understood as making contributions to (2'), since internalizing these theoretical views can help one cultivate her life in accordance with (1'), or some environmental conception of the good life. One might, for example, repeatedly meditate on the vastness of nature, which is to adopt a version of the view from above. Over time, this 
meditative practice has the potential to effect a transformation in oneself, building environmental humility or acceptance of nature, for example. Plausibly, this practice helps to remove obstacles to attaining these environmental virtues, such as fixation on disturbances in one's life. By routinely adopting this environmental form of the view from above, one can come to see disturbances in one's life as a miniscule parts of an enormous natural world. In that case, we can take this form of meditation to be an environmental spiritual exercise, for it instills environmental virtues through a transformative practice.

Yet one might question whether the view from above is actually a good perspective to adopt. First, perpetually maintaining this view presumably would be impossible for human beings. It is difficult even to imagine someone who never regards her own disturbances from a first-person perspective. Second, adopting the view from above might involve a problematic disengagement, perhaps by creating a kind of affective detachment or even apathy regarding, for example, the suffering of other persons. However, advocating the view from above need not involve a directive to maintain this view at all times, even if some ancient sources seem to advise doing so. Rather, adopting the view from above may be suggested as a temporary exercise meant to assist one's pursuit of the good life, given that sometimes we can be too invested in things closest to us. For example, in the grip of intense or prolonged suffering, it often may be both helpful and appropriate to attempt to view that suffering and its causes from a universal standpoint. This does not require us to adopt an apathetic stance toward others, since we may still hold that there are times when it is appropriate to adopt a firstperson perspective. For example, it may not be appropriate to extirpate all grief regarding the death of a friend, but there may be times when intense and prolonged grief should be assuaged, and the view from above may help do so. While precisely when the view from above is appropriate would depend on the specific conception of (1') in question, it would be too hasty to deny that this perspective can be useful. 
Which environmental spiritual exercises should be practiced will depend on the conception of (1') that is adopted. If some conception of the environmental good life grants an important place to ataraxia, then candidates for (2') can be evaluated partly for how well they assist their practitioners in approximating a life free of disturbance. Of course, environmental philosophy as a way of life need not take ataraxia to be a constituent of the good life. Perhaps instead of (or in addition to) ataraxia, a conception of (1') should include possessing certain environmental virtues. Fortunately, environmental philosophy offers remarkably rich possibilities for distinctively environmental spiritual exercises, ones that are compatible with various conceptions of (1'). I have discussed two options already: meditation on the vastness of nature and, by way of the example of Thoreau, interaction with nature through manual labor.

Another set of environmental spiritual exercises is tied to our dietary practices. Adopting a vegan or vegetarian diet in a certain way could, for example, habituate one to prioritizing the well-being of non-human animals over one's immediate desires (e.g., to enjoy the taste of meat), thereby cultivating environmental benevolence. In order to count as a spiritual exercise, such a practice must involve more than merely avoiding meat or animal products. In addition to that, one will remain mindful of why she eats certain foods and avoid others, and so her daily practices can serve as reminders of the environmental values she seeks to honor and the environmental virtues she seeks to craft or maintain. Another type of environmental spiritual exercise is environmental writing. For example, recording one’s environmental experiences in writing, as Leopold does in A Sand County Almanac, might serve as a transformative practice, perhaps helping to internalize and reinforce the values and beliefs that contribute to the pursuit of certain environmental virtues, like respect for nature (Leopold, 2001). The act of writing allows one to recall, appreciate, and organize one’s experiences in the natural world. It can serve as a reminder of the value of those experiences. 


\section{Closing Remarks}

I have argued both that philosophy as a way of life is worth reviving and that environmental philosophy is well-suited to enact such a revival. Environmental philosophy as a way of life would involve both (1') some distinctively environmental conception of the good life and (2') a set of environmental spiritual exercises to cultivate that life in oneself. I have suggested some possible forms (1') and (2') might take, but I have neither advocated nor argued for any particular conception of the environmental good life, nor for any particular set of environmental spiritual exercises. The task of advocating specific forms of (1') and (2') would require us to engage in (3), or rational reflection on which of them are most deserving of our acceptance and practice. This task requires more space that I have available here. Nonetheless, I hope to have shown that environmental philosophy as a way of life is an attractive possibility, for there is good reason to think that it could help us make good on the desire to lead a flourishing life.

\section{Bibliography}

Aristotle. 1999. Nicomachean Ethics. Translated by T. Irwin. Indianapolis, Hackett.

Aurelius, M. 1983. The Meditations. Translated by G. M. A. Grube. Indianapolis, Hackett.

Booth, C. 2009. “A Motivational Turn for Environmental Ethics.” Ethics \& the Environment 14(1): 53-78.

Cafaro, P. (2005). “Thoreau, Leopold, and Carson: Toward an Environmental Virtue Ethics.” In P. Cafaro and R. Sandler (eds.), Environmental Virtue Ethics. Lanham, Rowman and Littlefield. 
Cafaro, P. and R. Sandler (eds.). 2005. Environmental Virtue Ethics. Lanham, Rowman and Littlefield.

Cicero. 1927. Tusculan Disputations. Translated by J. E. King. Cambridge, Harvard University Press.

Coeckelbergh, M. 2015. Environmental Skill: Motivation, Knowledge, and the Possibility of a Non-Romantic Environmental Ethics. New York, Routledge.

Davidson, A. (1995). “Introduction.” In P. Hadot, Philosophy as a Way of Life: Spiritual Exercises from Socrates to Foucault. Translated by M. Chase. Hoboken, Wiley. Epictetus (1928). Epictetus: Discourses, Books 3-4; The Encheiridion. Cambridge, Harvard University Press.

Foucault, M. 1986. The Care of the Self: Volume 3 of the History of Sexuality. Translated by R. Hurley. New York, Random House.

Foucault, M. (1997). “Self-Writing.” In P. Rabinow (ed.), Ethics: Subjectivity and Truth. New York, New Press.

Foucault, M. 2005. The Hermeneutics of the Subject: Lectures at the Collège de France 1981-1982. Translated by G. Burchell. New York, St. Martin’s Press.

Goralnik, L. and M. P. Nelson. 2011. "Framing a Philosophy of Environmental Action: Aldo Leopold, John Muir, and the Importance of Community.” The Journal of Environmental Education 42(3): 181-192.

Hadot, P. 1995. Philosophy as a Way of Life: Spiritual Exercises from Socrates to Foucault. Translated by M. Chase. Hoboken, Wiley.

Hadot, P. 2002. What Is Ancient Philosophy? Translated by M. Chase. Cambridge, Harvard University Press.

Hadot, P. (2005). “There Are Nowadays Professors of Philosophy, but not Philosophers.” Journal of Speculative Philosophy 19(3): 229-237. 
Hill, T. (2005). “Ideals of Human Excellence and Preserving Natural Environments.” In P. Cafaro and R. Sandler (eds.), Environmental Virtue Ethics. Lanham, Rowman and Littlefield.

Hursthouse, R. 1996. “Normative Virtue Ethics.” In R. Crisp (ed.), How Should One Live? Oxford, Oxford University Press.

Hursthouse, R. 1999. On Virtue Ethics. Oxford, Oxford University Press.

Irvine, W. 2008. A Guide to the Good Life: The Ancient Art of Stoic Joy. New York, Oxford University Press.

Kant, I. 1999. Practical Philosophy. Translated by M. J. Gregor. Cambridge, Cambridge University Press.

Leopold, A. 2001. A Sand County Almanac. New York, Oxford University Press.

Long, A. A. and D. N. Sedley. 1987. The Hellenistic Philosophers: Volume 1, Translations of the Principal Sources with Philosophical Commentary. Cambridge, Cambridge University Press.

Nussbaum, M. 1994. The Therapy of Desire: Theory and Practice in Hellenistic Ethics. Princeton University Press.

Nussbaum, M. 1999. “Virtue Ethics: A Misleading Category?” The Journal of Ethics 3(3): 163-201.

O'Neill, J. 1992. “The Varieties of Intrinsic Value.” Monist 75(2): 119-137.

Plotinus. 1969. Plotinus: Porphyry on Plotinus, Ennead I. Translated by A. H. Armstrong. Cambridge, Harvard University Press.

Rolston III, H. 1982. “Are Values in Nature Subjective or Objective?” Environmental Ethics 4(2): $125-151$.

Rufus, M. 2011. Musonius Rufus: Lectures and Sayings. Translated by C. King. CreateSpace. 
Sandler, R. 2005. “A Virtue Ethics Perspective on Genetically Modified Crops.” In P. Cafaro and R. Sandler (eds.). Environmental Virtue Ethics. Lanham, Rowman and Littlefield. Sandler, R. 2009. Character and Environment: A Virtue-Oriented Approach to Environmental Ethics. New York, Columbia University Press.

Seneca. 1961. Epistulae Morales, Volume I. Translated by R. M. Gummere. Cambridge, Harvard University Press.

Seneca. 1979. De Ira. In Seneca, Moral Essays, Volume 1. Translated by John W. Basoe. Cambridge, Harvard University Press.

Shrader-Frechette, K. 2000. “Duties to Future Generations, Proxy Consent, Intra- and Intergenerational Equity: The Case of Nuclear Waste.” Risk Analysis 20(6): 771-778.

Svoboda, T. 2012. “Duties Regarding Nature: A Kantian Approach to Environmental Ethics.” The Kant Yearbook 4: 143-163.

Svoboda, T. 2015. Duties Regarding Nature: A Kantian Environmental Ethic. New York, Routledge.

Sylvan, R. 2003. “Is There a Need for a New, an Environmental Ethic?” In A. Light and H. Rolston III, Environmental Ethics: An Anthology. Malden, Blackwell.

Taylor, P. 1986. Respect for Nature: A Theory of Environmental Ethics. Princeton, Princeton University Press.

Thoreau, H. D. 2004. Walden: A Fully Annotated Edition. New Haven, Yale University Press.

Thoreau, H. D. 2013. “Life Without Principle.” In J. S. Cramer (ed.), Essays: A Fully Annotated Edition. New Haven, Yale University Press. 